\title{
Expression and Antibody Production of Japanese Encephalitis Virus RNA Polymerase (NS5) Protein
}

\author{
Jeong-Min Kim, Sang-Im Yun, Byung-Hak Song, Yu-Jeong Choi, Jun-Sun Park \\ and Young-Min Lee*
}

Department of Microbiology, College of Medicine and Medical Research Institute, Chungbuk National University, Cheongju, Korea

\begin{abstract}
Japanese encephalitis virus (JEV), a member of mosquito-borne flaviviruses, is the leading cause of viral encephalitis in a large geographic area of Southeast Asia and Australia. JEV contains a single-stranded positive-sense RNA genome, which encodes its own RNA-dependent RNA polymerase (NS5) that is required for genomic RNA replication. In this study, we have described a pair of mouse antisera specific to the N- or C-terminal region of the NS5. Initially, two hydrophilic regions corresponding to the N-terminus and C-terminus of the NS5 protein were individually amplified by reverse transcription-PCR from the genomic RNA of JEV K87P39 strain. The amplified DNA fragments were cloned into a prokaryotic expression vector, pGEX-4T-1; the resulting constructs were used for the expression of GST fusion proteins, designated GST/NS5N and GST/NS5C, in E. coli BL-21 strain. Following immunization of three BALB/c mice with each of the purified GST/NS5N and GST/NS5C, we obtained two pools of the antisera, specifically recognizing the $\sim 103-\mathrm{kDa}$ NS5 and several smaller NS5-related proteins in BHK-21 and Vero cells infected with JEV K87P39 strain. Overall, we have successfully expressed the N- and C-terminal regions of JEV NS5 fused to the C-terminus of GST and generated the mouse antisera capable of recognizing the NS5 and its related proteins in JEV-infected cells. This would provide a valuable reagent for the study of JEV NS5 in the viral life cycle.
\end{abstract}

Key Words: Japanese encephalitis virus; Flavivirus; RNA-dependent RNA polymerase; NS5

\section{서 론}

일본뇌염바이러스 (Japanese encephalitis virus, JEV)는 작은 빨간집 모기 (Culex tritaeniorhynchus)에 의해 전파 되며 인체 감염시 급성뇌염을 일으킨다. 일본뇌염바이러 스는 한국, 중국, 일본, 인도, 베트남 등을 포함한 동남아 시아의 대부분 지역에서 유행하고 있다 $(1,2)$. 통계학적 으로 매년 약 50,000 명 정도의 발병환자가 보고되고 있

Received: March 6, 2009/ Revised: March 16, 2009

Accepted: March 17, 2009

* Corresponding author: Young-Min Lee. Department of Microbiology, College of Medicine \& Medical Research Institute, Chungbuk National University, 12 Gaeshin-Dong, Heungduk-Ku, Cheongju, Korea.

Phone: +82-43-261-2863, Fax: +82-43-272-1603

e-mail: ymlee@chungbuk.ac.kr

** This work was supported by a Korea Research Foundation grant (KRF2004-202-C00405, which was transferred from R05-2004-000-11090-0) funded by the Korean Government (MOEHRD).
으며, 이 중에서 약 15,000 명은 사망한다 (3). 특히 어린 이와 유아의 경우 치료 후에도 심각한 신경성 후유증을 경험할 가능성이 높다 $(4,5)$. 최근 지구의 기온상승과 생 활환경의 변화로 인해서 일본뇌염바이러스의 감염지역 이 점차 확대되고 있다. 특히, 과거에는 일본뇌염바이러 스가 발견되지 않았던 호주에서 최근 2 3년 동안 지속 적으로 바이러스가 분리되고 있어, 전세계적으로 주요 병 원성 바이러스의 하나로 대두되고 있다 (6 9).

일본뇌염바이러스는 분류학적으로 플라비비리데 과 (Flaviviridae family)의 플라비바이러스 속 (Flavivirus genus)에 속하며, 유전학적으로 황열바이러스 (yellow fever virus), 웨스트나일바이러스 (West Nile virus, WNV) 및 뎅 기바이러스 (dengue virus, DENV)와 매우 유사하다 (10, 11). 다른 플라비바이러스와 마찬가지로, 일본뇌염바이러 스는 약 11,000 개의 염기로 구성된 단일가닥의 양성-극 성 RNA를 게놈으로 가지고 있다. 게놈의 5'-말단에는 
캡-1 구조 (cap-1 structure)를 가지고 있으나, 3'-말단에는 폴리 A 꼬리 [poly(A) tail]을 가지고 있지 않다 $(12,13)$. 게놈은 단 한 개의 open reading frame (ORF)으로 구성되 어 있으며, 이 $\mathrm{ORF}$ 의 양쪽 끝부분에 단백질을 인코딩하 지 않는 비번역부위 (nontranslated region, NTR)가 위치한 다. 바이러스의 ORF는 하나의 다단백질 (polyprotein)로 합성된 후, 최소 2 개의 단백질 분해효소에 의해서 3 개 의 구조단백질 (structural protein)과 7 개의 비구조단백질 (nonstructural protein, NS)로 분해된다. 3개의 구조단백질 은 capsid (C), premembrane (prM) 및 envelope (E)이라고 부르며, 7개의 비구조단백질은 NS1, NS2A, NS2B, NS3, NS4A, NS4B 및 NS5라고 명명한다 $(13,14)$.

일본뇌염바이러스를 포함한 모든 플라비바이러스의 NS5 $(\sim 103 \mathrm{kDa})$ 은 서로 다른 분리주들 간에 염기서열의 이질성 (heterogeneity)이 매우 낮으며, methyltransferase와 RNA-dependent RNA polymerase (RdRp)의 기능을 겸비한 다기능 단백질로 알려져 있다. Methyltransferase의 기능은 바이러스의 게놈 5'-말단에 캡 구조를 첨가하는 반응에 관여하며 $(15,16), \mathrm{RdRp}$ 의 기능은 게놈 RNA의 복제를 수행하는 역할을 하는 데 기여하는 것으로 보고된 바 있 다 (17 19). 비록 이러한 NS5의 생물학적 특징은 정제된 단백질을 사용하여 입증된 바는 있으나, 이들이 어떠한 작용기전에 의해서 바이러스의 RNA 복제에 관여하는 지 에 대한 자세한 사항은 거의 규명된 바 없다. 또한 알려 진 기능 이외에 NS5 단백질은 플라비바이러스의 증식에 중요한 역할을 하는 것으로 추정된다. 뎅기바이러스의 경우, NS5가 사이토카인 IL-8의 전사와 분비를 증대시킴 으로써 바이러스의 전파를 촉진한다고 보고된 바 있다 (20). 그리고 진드기에 의해서 전파되는 플라비바이러스 (tick-borne encephalitis virus)의 경우, NS5가 인터페론 수 용체와 결합함으로써 IFN- $\alpha / \beta$ 와 IFN- $\gamma$ 의 신호전이를 방 해하고, Jak1과 Tyk2의 인산화를 감소시켜 STAT 1 의 활 성화를 억제한다는 사실이 보고된 바 있다 (21). 앞으로 NS5 단백질이 플라비바이러스의 생활사에서 어떠한 기 능을 하는 지에 대한 자세한 연구가 필요할 것으로 사료 된다.

본 연구에서는 E. coli 발현시스템을 활용하여 일본 뇌염바이러스 NS5 단백질의 두 부위를 glutathione $S$ transferase (GST) fusion protein 형태로 각각 다량 발현하 고, 정제된 재조합 단백질을 면역원으로 사용하여 마우 스 항혈청을 생산하고자 하였다. 이렇게 얻어진 단백질
과 항혈청은 앞으로 일본뇌염바이러스의 기초연구, 특히 바이러스 생활사에서 NS5의 역할과 작용기전을 규명하 는 데 중요한 실험시약으로 활용할 수 있을 것으로 기 대한다.

\section{재료 및 방법}

세포 및 바이러스

본 연구에서는 BHK-21과 Vero 세포주를 바이러스 감 염실험에 사용하였다. 이들 세포주는 모두 $10 \%$ 우태아 혈청 (fetal bovine serum), $2 \mathrm{mM} \mathrm{L}$-글루타민, 비타민 및 페 니실린/스트렙토마이신을 첨가한 alpha minimum essential medium ( $\alpha$-MEM)에서 배양하였으며, $37^{\circ} \mathrm{C}, 5 \% \mathrm{CO}_{2}$ 조건 에서 약 3 4일 마다 분주하였다. 본 실험에 사용한 일 본뇌염바이러스는 1987년 모기에서 분리된 한국분리주 $\mathrm{K} 87 \mathrm{P} 39$ 를 사용하였다 (22).

\section{플라스미드}

일본뇌염바이러스 NS5 단백질의 N-말단부위로부터 275 개의 아미노산을 발현하는 pGEX/JevNS5N과 C-말단 부위에서 463 개의 아미노산을 발현하는 pGEX/JevNS5C 플라스미드를 각각 제조하였다. 플라스미드 클로닝과 관 련된 모든 사항은 일반적인 재조합 DNA 기술 (recombinant DNA technology)를 사용하였다 (23). 먼저 일본뇌 염바이러스의 국내분리주인 K87P39 (GenBank accession no. AY585242)의 게놈 RNA을 주형으로 사용하여 RT$\mathrm{PCR}$ 를 수행함으로써 JevNS5N과 JevNS5C에 해당하는 $\mathrm{cDNA}$ 를 각각 합성하였다. RT-PCR 반응에 사용한 프라 이머는 JevNS5N cDNA의 경우 B-ns5-F/B-Nns5-R를 사용 하였으며, JevNS5C cDNA의 경우 B-Cns5-F/B-ns5-R를 사 용하였다 (Table 1). 합성된 cDNA 단편은 EcoR I과 Xho I 으로 처리한 후, 같은 제한효소로 처리된 pGEX-4T-1 발 현벡터 (GE Healthcare, Piscataway, NJ, USA)에 삽입하였 다. 클로닝된 JevNS5N과 JevNS5C cDNA는 GST 단백 질의 C-말단부위에 융합되어 GST fusion protein 형태로 발현되도록 고안하였다 (Fig. 1). Reverse transcription (RT)-PCR로 증폭된 부위는 최종적으로 염기서열분석을 통해서 삽입된 염기서열이 기존의 K87P39 분리주와 일 치함을 확인하였다. 
RT-PCR

역전사반응 (reverse transcription reaction)은 $100 \mathrm{U}$ 의 Superscript II 역전사효소 (Invitrogen, Carlsbad, CA, USA)를 사용하여 $20 \mu \mathrm{l}$ 반응액에서 수행하였다. 일반적인 반응액 의 조성은 Superscript II 역전사효소와 함께 $10 \mu \mathrm{l}$ 의 추출 된 바이러스 게놈 RNA, $5 \mathrm{pmol}$ reverse 프라이머, $40 \mathrm{U}$ RNaseOUT (Invitrogen), $0.1 \mathrm{mM}$ dithiothreitol (DTT) 및 10 $\mathrm{mM}$ deoxynucleoside triphosphate mix를 포함하였다. 역전 사반응은 $37^{\circ} \mathrm{C}$ 에서 1 시간 동안 지속되었으며, $70^{\circ} \mathrm{C}$ 에서 15 분 동안 가열함으로써 효소를 불활화시켰다. 그리고 PCR 반응은 5 U의 Pyrobest DNA polymerase (Takara, Shiga, Japan)를 사용하여 $100 \mu \mathrm{l}$ 반응액에서 수행하였다. PCR 반응액은 Pyrobest DNA polymerase를 포함하여 $10 \mathrm{mM}$ Tris (pH 8.3), $1.5 \mathrm{mM} \mathrm{MgCl}_{2}, 50 \mathrm{mM} \mathrm{KCl,} 200 \mu \mathrm{M}$ dNTPs 및 $0.4 \mu \mathrm{M}$ forward와 reverse 프라이머로 구성하였다. PCR 증폭사이클은 denaturation $\left(94^{\circ} \mathrm{C}, 30\right.$ 초), annealing $\left(60^{\circ} \mathrm{C}, 30\right.$ 초) 및 polymerization $\left(72^{\circ} \mathrm{C}, 1\right.$ 분)으로 구성하였으며, 총 30 사이클을 실시하였다.

\section{단백질 발현 및 정제}

$\mathrm{pGEX} / \mathrm{JevNS} 5 \mathrm{~N}$ 과 $\mathrm{pGEX} / \mathrm{JevNS} 5 \mathrm{C}$ 를 각각 E. coli BL-21 competent cell에 형질전환 (transformation)한 후, 암피실린 이 첨가된 $\mathrm{LB}$ 플레이트에 $37^{\circ} \mathrm{C}$ 에서 12 시간 배양하였다. 각각 하나의 독립된 콜로니를 암피실린이 첨가된 $\mathrm{LB}$ 배 양액에서 12 시간 배양한 후, 총 $250 \mathrm{ml}$ 의 배양액에 $1: 50$ 으로 희석한 다음 $\mathrm{A}_{600}$ 흡광도가 $0.6 \sim 1.0$ 의 범위에 올 때까지 1 시간 30 분간 다시 배양하였다. 이후 $0.2 \mathrm{mM}$ 의 isopropyl- $\beta$-thiogalactoside (IPTG)를 첨가하여 4시간 동안 GST fusion protein의 발현을 유도하였다.

재조합 단백질을 정제하기 위해서 배양된 E. coli를 원 심분리하여 침전물 (pellet)을 수확한 후, $23.5 \mathrm{ml}$ 의 인산 완충용액 (phosphate-buffered saline, PBS)에 재부유시켰다. 부유액에 $1 \%$ Triton X-100를 첨가한 후 30 분간 실온에서 방치한 다음, $12,000 \mathrm{rpm}$ 의 속도로 $4^{\circ} \mathrm{C}$ 에서 20 분간 원심 분리하여 상층액을 수확하였다. 얻어진 상층액으로부터 GST fusion protein은 glutathione sepharose 4-fast flow beads (GE Healthcare)을 사용하여 제조사가 제공하는 지침서에 따라서 단백질을 정제하였다. 정제된 단백질은 $\mathrm{A}_{280}$ 흡 광도를 측정한 후 Bradford 단백질 정량법으로 정량하였 다. 정제된 단백질은 $12 \%$ SDS-polyacrylamide gel electro- phoresis (SDS-PAGE)를 통해서 분리한 다음, coommasie staining 방법으로 염색하여 원하는 단백질의 수확량을 분석하였다 (23).

\section{항혈청 생산}

$\mathrm{pGEX} / \mathrm{JevNS} 5 \mathrm{~N}$ 과 $\mathrm{pGEX/JevNS5C}$ 벡터로부터 정제된 단백질 $(\mathrm{GST} / \mathrm{JevNS} 5 \mathrm{~N}$ 과 $\mathrm{GST} / \mathrm{JevNS} 5 \mathrm{C})$ 을 면역원으로 사 용하여, $\mathrm{SPF} \mathrm{BALB} / \mathrm{c}$ (4주령) 마우스의 복강에 총 6 차례 접종하였다. 1 차 접종은 $500 \mu \mathrm{l}$ 의 정제된 단백질 $(100 \mu \mathrm{g} /$ $\mathrm{ml}$ )에 $500 \mu \mathrm{l}$ 의 complete Freund adjuvant를 섞어서 주사하 였으며, 2 6차 접종은 $500 \mu \mathrm{l}$ 의 정제된 단백질 $(100 \mu \mathrm{g}$ $\mathrm{ml}$ )에 $500 \mu \mathrm{l}$ 의 incomplete Freund adjuvant를 섞어서 주사 하였다. 1 2차 접종은 2주 간격으로 실시하였으며, 2 6 차 접종은 1 주 간격으로 실시하였다. 접종 스케줄이 끝 난 후, 그룹별로 3 마리의 마우스에서 얻어진 혈청을 혼 합하였다.

\section{웨스턴 블롯}

$\mathrm{pGEX} / \mathrm{JevNS} 5 \mathrm{~N}$ 과 $\mathrm{pGEX/JevNS5C}$ 벡터로부터 정제된 단백질 $(\mathrm{GST} / \mathrm{JevNS} 5 \mathrm{~N}$ 과 $\mathrm{GST} / \mathrm{JevNS} 5 \mathrm{C})$ 에 존재하는 $\mathrm{GST}$ fusion protein을 동정하기 위해서, 또한 본 연구에서 얻어 진 NS5 단백질에 대한 항혈청을 테스트하기 위해서 웨 스턴 블롯을 실시하였다. GST fusion protein을 동정하기 위해서는 정제된 단백질을 직접 샘플로 사용하였으며, 항 혈청을 분석하기 위해서는 일본뇌염바이러스에 감염된 세포 (실험군)와 감염되지 않은 세포 (대조군)를 sample loading buffer $(80 \mathrm{mM}$ Tris- $\mathrm{HCl}$ [pH 6.8], 2.0\% SDS, 10\% glycerol, 0.1M DTT, 0.2\% bromophenol blue)로 직접 용해 시켰다. 이렇게 얻어진 cell lysate에 존재하는 단백질은 $12 \% \mathrm{SDS}-\mathrm{PAGE}$ 로 분리한 후, 메탄올로 전처리된 $\mathrm{PVDF}$ membrane (Millipore, Billerica, MA, USA)에 전기영동을 통 해서 이동시켰다. Membrane은 1차 항체로써 GST에 특이 적으로 반응하는 단클론항체 (AbFrontier, Seoul, Korea) 또 는 본 연구에서 얻어진 마우스 항혈청으로 염색한 다음, 2차 항체로 alkaline phosphatase (AP)-conjugated goat antimouse IgG 항체 (Jackson ImmunoResearch Labs, West Grove, PA, USA)로 염색하였다. 1차 및 2차 항체로 염색 된 membrane은 $\mathrm{AP}$ 의 기질인 $\mathrm{BCIP}$ (5-bromo-4-chloro-3indolylphosphate)/NBT (nitroblue tetrazolium) 혼합용액으로 염색하였다. 
Table 1. Primers used for PCR amplification in this study

\begin{tabular}{|c|c|c|c|}
\hline Primer & Sequence $^{a}$ & Polarity & Size (mer) \\
\hline B-ns5-F & 5'-GAT & Sense & 27 \\
\hline B-Nns5-R & 5'-ATCCTCGAGCTAGTGGTATGTCCAAGTGCG-3' & Antisense & 30 \\
\hline B-Cns5-F & 5'-GATGGATCCGAGTGTCACACATGTATC-3' & Sense & 27 \\
\hline B-ns5-R & 5'-ATCCTCGAGTTACTAGATGACCCTGTC-3' & Antisense & 27 \\
\hline
\end{tabular}

${ }^{a} \mathrm{JEV}$-specific sequences are indicated in boldface types.

Restriction recognition sites used for cloning are underlined

(A)

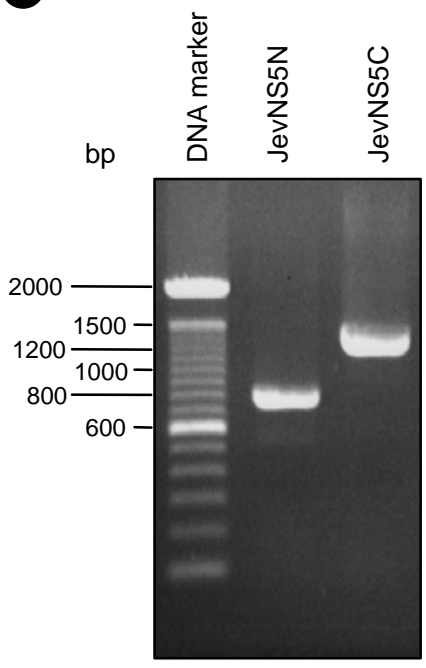

B

pGEX-4T-1

pGEX/JevNS5N

pGEX/JevNS5C
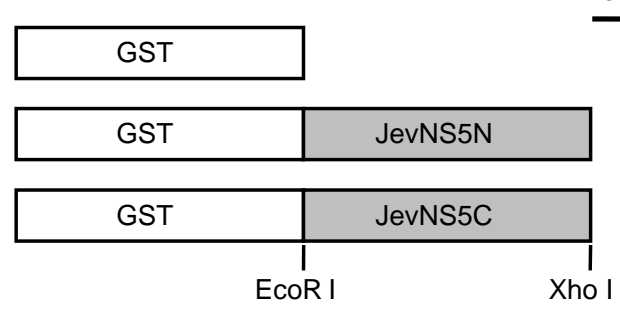

$\sim 61$

$\sim 28$

Figure 1. PCR amplicons of JevNS5N and JevNS5C (A) and schematic presentation of pGEX/ JevNS5N and pGEX/JevNS5C constructs (B). The JEV NS5N and NS5C regions were PCRamplified with an appropriate pair of primers as indicated in the text. The amplicons were separated by $1 \%$ agarose gel electrophoresis and stained with ethidium bromide (A). pGEX/ JevNS5N and pGEX/JevNS5C constructs were designed to express the N-terminal region (275 amino acids) and C-terminal region (461 amino acids) of JEV NS5 protein, respectively (B).

\section{결 과}

일본뇌염바이러스 NS5 단백질의 N-말단부위와 C-말단 부위를 각각 발현하는 벡터의 합성

먼저 일본뇌염바이러스의 RNA 복제에 필수적인 $\mathrm{RdRp}$ 인 full-length NS5 단백질을 원핵세포 발현벡터를 사용 하여 E. coli에서 GST fusion protein 형태로 발현하고자 시도하였다. 그러나 여러 차례의 실험결과 온전한 NS5 단백질은 E. coli에서 발현이 거의 되지 않음을 경험하였 다 (자료 미제시). 따라서, NS5 단백질을 $\mathrm{N}$-말단부위와 $\mathrm{C}$-말단부위로 나누어 발현을 유도하고자 하였다. E. coli 에서 재조합 단백질을 soluble form으로 발현시키고자, DNA strider 프로그램을 사용하여 full-length NS5 단백질 의 hydropathy 분포도를 분석하였다. 이 분석결과를 토대 로 NS5 단백질의 N-말단과 C-말단부위가 친수성이 높을 것으로 추정되었으며, 이 부위를 본 실험에 사용하였다.

일본뇌염바이러스의 한국분리주 K87P39로부터 분리된 genomic RNA를 주형으로 사용하고, Table 1에 열거된 프 라이머를 이용하여 NS5 단백질의 N-말단부위에 해당하 는 JevNS5N (프라이머: B-ns5-F/B-Nns5-R)과 C-말단부위 에 해당하는 JevNS5C (프라이머: B-Cns5-F/B-ns5-R) cDNA 단편을 각각 증폭하였다. 총 905 개의 아미노산으로 구성 된 NS5 단백질로부터 JevNS5N cDNA는 N-말단의 275개 아미노산에 해당하는 부위이며, JevNS5C cDNA는 C-말단 의 461 개 아미노산에 해당하는 부위이다. RT-PCR 증폭 결과 합성된 cDNA 단편의 크기를 알아보기 위해서 $1 \%$ agarose gel을 사용하여 전기영동을 실시하였으며, ethidium bromide로 염색하였다. JevNS5N의 경우 825 base pair (bp)의 cDNA가 증폭되었고, JevNS5C의 경우 1,383 bp 의 cDNA가 증폭되었다 (Fig. 1A). 이들의 크기는 예상한 것과 일치하였다.

이와 같이 증폭된 $\mathrm{cDNA}$ 단편은 클로닝을 원활하게 수 행하기 위해서 인위적으로 프라이머의 5'과 3' 말단에 각 각 삽입한 EcoR I과 Xho I 제한효소를 사용하여 E. coli 발현벡터인 pGEX-4T-1에 삽입하였다. Fig. 1B에 나타낸 
것과 같이 삽입된 JevNS5N과 JevNS5C는 모두 pGEX4T-1이 인코딩하고 있는 GST 단백질의 C-말단부위에 융

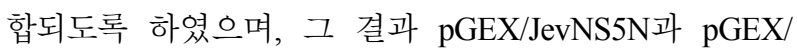
$\mathrm{JevNS5C}$ 이라고 명명된 플라스미드를 합성하였다. 삽입 한 $\mathrm{cDNA}$ 의 염기서열은 RT-PCR을 위해 주형으로 사용 한 일본뇌염바이러스 K87P39의 염기서열과 일치함을 확 인하였다.

\section{GST/JevNS5N과 GST/JevNS5C 단백질의 발현 및 정제}

$\mathrm{pGEX} / \mathrm{JevNS} 5 \mathrm{~N}$ 과 $\mathrm{pGEX/JevNS5C}$ 발현벡터를 사용하여 E. coli BL-21 세포에서 GST fusion protein (GST/JevNS5N 과 $\mathrm{GST} / \mathrm{JevNS} 5 \mathrm{C}$ )을 다량으로 발현 및 정제하고자 하였 다. 이를 위해서 각각의 발현벡터로 형질전환된 BL-21 세포에 IPTG를 첨가하여 4시간 동안 원하는 GST fusion protein의 발현을 유도하였다. 발현된 재조합 단백질은 GST column을 사용하여 정제하였으며, 원하는 단백질의

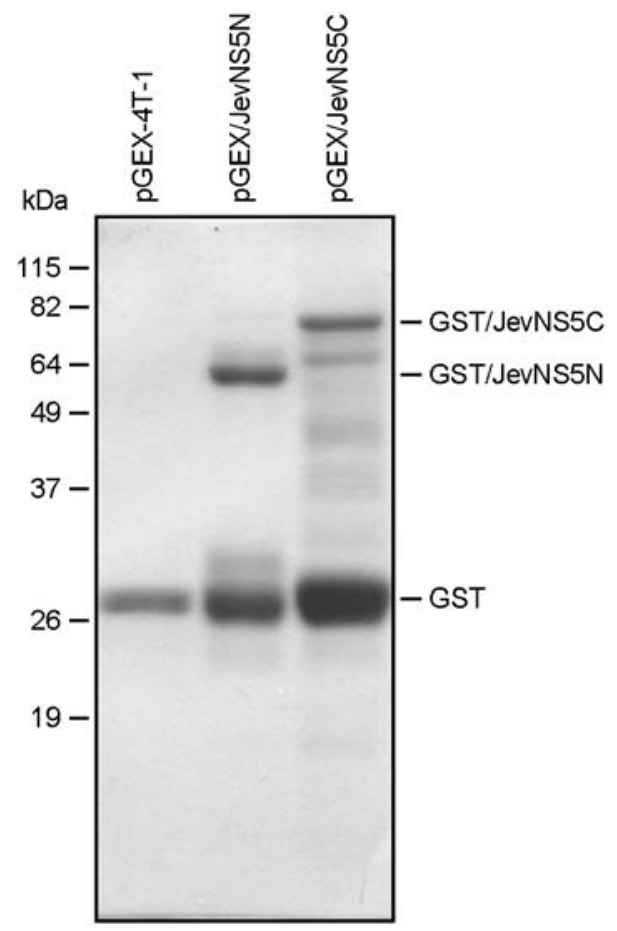

Figure 2. Expression of GST/JevNS5N and GST/JevNS5C proteins (coommasie staining). The E. coli. BL-21 cells were transformed with the parental pGEX-4T-1 or one of two recombinant plasmids designated pGEX/JevNS5N and pGEX/JevNS5C. The expression of the recombinant proteins (GST/JevNS5N and GST/ JevNS5C) was analyzed by $12 \%$ SDS-PAGE and coommasie staining. The molecular weight markers in $\mathrm{kDa}$ were indicated on the left and the sizes of GST, GST/JevNS5N, and GST/JevNS5C were shown on the right.
발현여부와 수확량을 알아보기 위해서 정제된 샘플을 $12 \%$ SDS-PAGE로 분리한 후 coommasie staining을 수행 하였다.

pGEX/JevNS5N 발현벡터로 형질전환된 BL-21 세포에 서는 예상했던 것과 유사한 크기의 GST/JevNS5N ( 61 $\mathrm{kDa}$ ) 단백질과 함께, 이 보다 작은 크기 (예: $\sim 28-\mathrm{kDa}$ 와 30-kDa)의 단백질들이 다수 발현되는 것을 알 수 있었 다 (Fig. 2, pGEX/JevNS5N). 단백질의 크기를 기준으로 하면, $\sim 28-\mathrm{kDa}$ 단백질 밴드는 $\mathrm{GST}$ 에 해당하며, $\sim 30-\mathrm{kDa}$ 단백질은 GST/JevNS5N의 truncated form이거나 또는 단 백질 발현시 internal initiation에 의해서 발현된 것으로 추정된다. 또한, $\mathrm{pGEX/JevNS5C} \mathrm{발현벡터로} \mathrm{형질전환된}$ BL-21 세포에서도 $\mathrm{pGEX/JevNS5N}$ 의 경우와 유사한 실험 결과를 얻었다. 즉, $\mathrm{GST} / \mathrm{JevNS} 5 \mathrm{C}(\sim 79-\mathrm{kDa})$ 의 단백질과 함께 이 보다 작은 크기의 여러 단백질들이 함께 발현

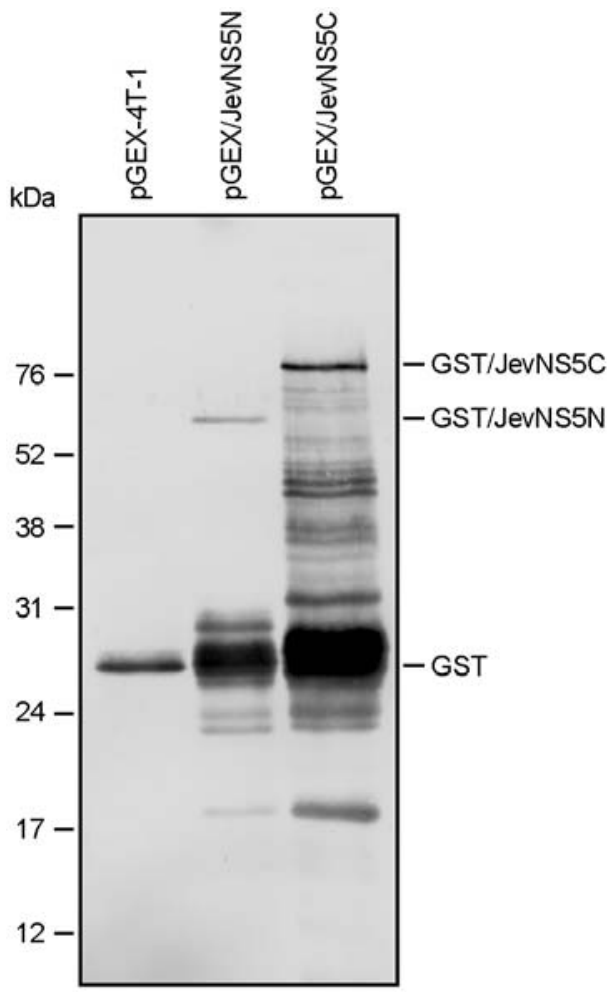

Figure 3. Identification of GST/JevNS5N and GST/JevNS5C proteins (immunoblotting). The parental pGEX-4T-1 or one of two recombinants (pGEX/JevNS5N and pGEX/JevNS5C) was transformed into E. coli BL-21 cells. Each culture was incubated in the presence of IPTG to induce the GST fusion proteins designated GST/JevNS5N and GST/JevNS5C. Following purification of the recombinant proteins with a glutathione sepharose column, the GST fusion proteins were separated by $12 \%$ SDS-PAGE and immunostaining with a GST-specific mouse monoclonal antibody. 

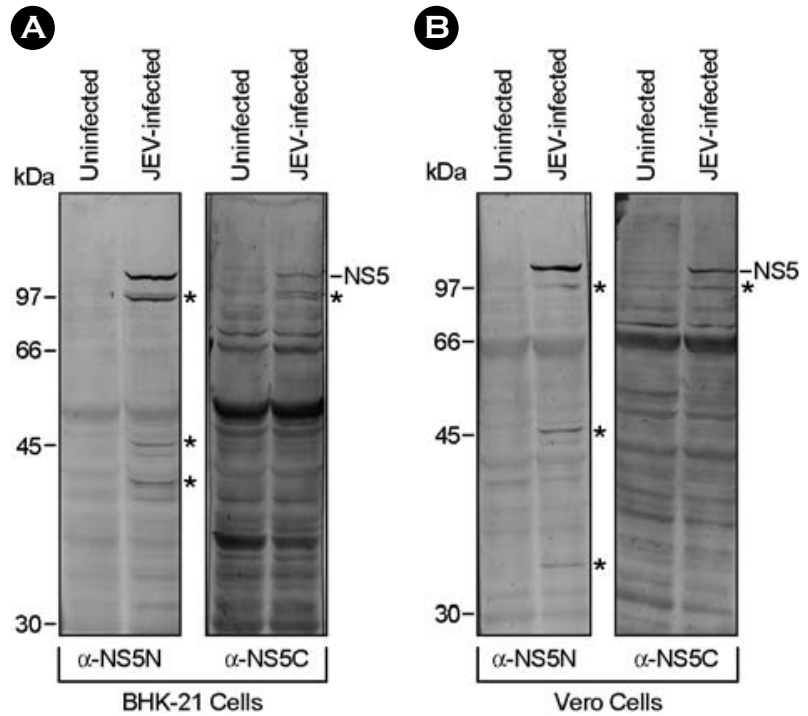

Figure 4. Immunoblotting with two mouse antisera raised against GST/JevNS5N and GST/JevNS5C. BHK-21 or Vero cells were mock-infected or infected with JEV K87P39 strain at an MOI of 1 . At $20 \mathrm{~h}$ post-infection, cells were directly lysed with 1 $\times$ sample loading buffer and the cell lysates were separated by $12 \%$ SDS-PAGE. The NS5 and NS5-related proteins (asterisks) were recognized by two mouse antisera ( $\alpha$-NS5N and $\alpha$-NS5C) raised against GST/JevNS5N and GST/JevNS5C, respectively. Molecular weight markers (in $\mathrm{kDa}$ ) were shown on the left and the sizes of NS5 and its related proteins were presented on the right.

및 정제되는 것을 알 수 있었다 (Fig. 2, pGEX/JevNS5C). 본 실험의 대조군으로 사용한 pGEX-4T-1 벡터로 형질전 환된 BL-21 세포의 경우, 대부분 28-kDa의 GST 단백질 임을 알 수 있었다 (Fig. 2, pGEX-4T-1).

다음으로, 이렇게 정제된 여러 개의 단백질들이 정말 로 GST fusion protein인지를 알아보기 위해서, GST에 특 이적으로 반응하는 단클론항체 (anti-GST Mab)를 사용하 여 웨스턴 블롯을 수행하였다. Coommasie staining의 실

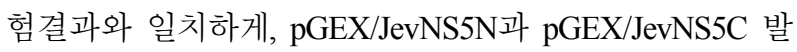
현벡터로 형질전환된 BL-21 세포에서 각각 $~ 61 \mathrm{kDa}$ 의 $\mathrm{GST} / \mathrm{JevNS} 5 \mathrm{~N}$ 과 $79-\mathrm{kDa}$ 의 GST/JevNS5C 단백질들이 각 각 탐지되었으며, 두 경우 모두 이 보다 작은 여러 개의 단백질들이 anti-GST Mab에 특이적으로 반응하는 것을 알 수 있었다 (Fig. 3).

일본뇌염바이러스의 NS5 단백질에 특이적으로 반응하는 항혈청 생산

최종적으로, E. coli에서 발현된 GST/JevNS5N과 GST/ $\mathrm{JevNS5C}$ 을 면역원으로 사용하여, BALB/c 마우스에서 항 혈청을 생산하고자 하였다. 먼저 정제된 단백질의 량을
Bradford 정량법에 의해서 측정한 후, 재료 및 방법에 기 술한 것과 같이 한 단백질당 3 마리의 마우스에 접종하 였다. 6차례의 접종스케줄이 끝난 다음, 마우스의 혈액 을 채취하여 각 그룹의 혈청을 풀링함으로써 anti-NS5N antiserum $(\alpha-\mathrm{NS} 5 \mathrm{~N})$ 과 anti-NS5C antiserum $(\alpha-\mathrm{NS} 5 \mathrm{C})$ 을 확 보하였다.

본 실험에서 얻어진 항혈청이 일본뇌염바이러스의 NS5 단백질을 특이적으로 인지하는 지를 알아보기 위해 서, 일본뇌염바이러스 K87P39로 감염된 BHK-21세포의 cell lysate을 사용하여 웨스턴 블롯을 수행하였다. 1 MOI (multiplicity of infection)의 일본뇌염바이러스에 감염된 BHK-21 (실험군)과 감염되지 않은 BHK-21 세포 (대조 군)를 바이러스 감염 후 20 시간이 경과한 다음 sample loading buffer로 직접 용해함으로써 total cell lysate을 확보 하였다. 이렇게 얻어진 샘플을 본 연구에서 확보한 2 개의 항혈청 ( $\alpha$-NS5N과 $\alpha-\mathrm{NS} 5 \mathrm{C})$ 을 사용하여 웨스턴 블롯을 수행하였다.

두 항혈청 모두 일본뇌염바이러스에 감염된 BHK-21 세포에서 $\sim 103-\mathrm{kDa}$ 크기의 NS5 단백질이 인지되었으며, 이 단백질 밴드는 바이러스가 감염되지 않은 세포에서는 탐지되지 않았다 (Fig. 4A). 또한, 예상하지 않았던 여러 개의 단백질들 (Fig. $4 \mathrm{~A}$, 별표)이 일본뇌염바이러스가 감 염된 세포에서 특이적으로 인지되는 것을 알 수 있었다. 다음으로, $\sim 103-\mathrm{kDa}$ 크기의 NS5 단백질 보다 작은 크기 의 여러 단백질들이 BHK-21 세포에서만 비정상적으로 나타나는 것인지, 아니면 다른 감염된 세포주에서도 관 찰되는 지를 알아보고자 일본뇌염바이러스에 감수성을 나타내는 또 다른 세포주인 Vero 세포를 사용하여 웨스 턴 블롯을 수행하였다. Fig. 4B에 나타낸 것과 같이, Vero 세포에서도 BHK-21 세포에서 관찰된 것과 같은 여러 개 의 단백질들이 $\alpha-\mathrm{NS} 5 \mathrm{~N}$ 과 $\alpha-\mathrm{NS} 5 \mathrm{C}$ 항혈청에 의해서 인지 되는 것을 알 수 있었다. 그러나, 이들이 BHK-21 세포에 서 인지된 것과 동일한 단백질인지는 알 수 없다. 그러므 로, 본 실험을 통해서 일본뇌염바이러스의 NS5 단백질에 특이적으로 반응하는 마우스 항혈청을 확보하였으며, 또 한 일본뇌염바이러스에 감염된 2 세포주에서 103-kDa 의 NS5 단백질 이외에 NS5 단백질과 연관된 크기가 작 은 다수의 바이러스 단백질이 존재하는 것을 발견하였다. 앞으로 이들에 대한 추가 연구를 통해서 NS5 단백질뿐만 아니라, 이와 연관된 단백질들이 바이러스의 증식에 어 떠한 역할을 규명할 필요가 있다. 


\section{고 찰}

본 연구에서 일본뇌염바이러스 NS5 단백질의 N-말단 부위 (275개 아미노산)와 C-말단부위 (461개 아미노산) 을 GST의 C-말단에 결합하여 GST fusion protein 형태로 E. coli에서 발현 및 정제를 하였으며, 이들에 대한 마우 스 항혈청을 각각 생산하였다. 이렇게 얻어진 항혈청은 일본뇌염바이러스가 감염된 세포 (BHK-21과 Vero)에서 $\sim 103-\mathrm{kDa}$ 크기의 NS5 단백질뿐 아니라, 기존에 알려지 지 않았던 여러 개의 NS5와 연관된 바이러스 단백질들을 인지하는 것을 알 수 있었다. 본 연구결과 합성된 재조 합 단백질과 항혈청은 앞으로 일본뇌염바이러스의 NS5 단백질이 게놈 RNA 복제뿐 아니라, 세포와 어떠한 상호 작용을 하는 지에 대한 연구에 기여할 것으로 생각된다.

지금까지 보고된 연구결과에 의하면 일본뇌염바이러스 를 포함한 플라비바이러스의 NS5 단백질은 methyltransferase와 $\mathrm{RdRp}$ 기능을 함께 가진 다기능 단백질이다 (13). 최근에 밝혀진 methyltransferase 기능의 경우, NS5의 N말단부위에 위치하고 있으며 게놈 RNA의 5'-말단에 캡 구조를 첨가하는 반응에 작용하는 것으로 알려져 있다 $(15,24)$. Methylation 반응에 작용하는 주요 아미노산을 다른 잔기로 치환시키면 바이러스의 증식이 억제된다는 사실이 보고된 바 있으며, 이것은 methyltransferase의 기 능이 바이러스의 복제 사이클에 매우 중요한 역할을 한다는 것을 의미한다 $(24,25)$. 특히 흥미로운 사실은 WNV NS5 단백질에 의한 guanine cap의 N-7 methylation 은 $\mathrm{WNV}$ 의 염기서열에 특이적으로 일어난다는 사실이 다 $(24,26)$. 이것은 $\mathrm{WNV} \mathrm{NS5}$ 가 바이러스의 5'-말단 또 는 다른 부위에 있는 특정 염기서열이나 2차 구조를 인 식하여, 바이러스에 특이적으로 methylation 반응에 작용 한다는 것을 의미한다. 앞으로 일본뇌염바이러스 NS5의 methyltransferase 기능에 대한 특성을 분석·비교함으로써, 이 바이러스에 대한 치료제 개발에 중요한 기초자료를 제공할 수 있을 것으로 기대한다.

NS5 단백질의 또 다른 주요 기능은 RdRp이며, 이 효 소의 활성은 새롭게 합성되는 게놈 RNA의 중합 (polymerization)에 직접 작용한다. 최근 in vitro assay를 통해서 $\mathrm{DENV} \mathrm{NS5}$ 의 RdRp가 게놈 RNA의 어떠한 부위를 처음 으로 인지하는 지, 어떠한 작용기전에 의해서 RNA 합성 이 시작되는 지에 대한 연구결과가 보고된 바 있다 (27
29). 이 연구결과에 따르면, NS5 단백질은 게놈 RNA의 5'-말단에 있는 특정 stem-loop structure를 최초로 인식하 여 이 부위에 결합하는 것으로 알려져 있다. 이후 NS5 단백질은 게놈 RNA의 3'-말단에 있는 또 다른 stem-loop structure (3'SL)로 이동한 후 RNA 합성을 시작하는 것으 로 추정된다. 다른 플라비바이러스와는 달리, 일본뇌염 바이러스의 경우 지금까지 적절한 항체와 다른 실험재료 들의 결핍으로 인해서 NS5 단백질에 대한 연구가 활발 하게 이루어지지 못했다. 본 연구에서 얻어진 일본뇌염 바이러스 NS5 단백질에 대한 항혈청은 앞으로 바이러스 복제시 이 단백질의 역할, 특히 proteolytic processing과 관련된 기능에 대한 특성 분석에 활용될 수 있을 것으로 기대한다. 또한 앞으로 NS5 단백질의 특정부위에 대한 단클론항체를 생산함으로써 일본뇌염바이러스와 유사한 다른 플라비바이러스의 감별진단 등에 활용될 수 있을 것으로 생각한다.

\section{참 고 문 헌}

1) Burke DS, Leake CJ. 1988. Japanese encephalitis, In Monath TP (ed.), The Arboviruses: Epidemiology and Ecology, vol III, pp.63-92, CRC Press, Florida.

2) Vaughn DW, Hoke CH Jr. The epidemiology of Japanese encephalitis: prospects for prevention. Epidemiol Rev 1992; 14:197-221.

3) Tsai TF. New initiatives for the control of Japanese encephalitis by vaccination: Minutes of a WHO/CVI meeting, Bangkok, Thailand, 13-15 October 1998. Vaccine 2000;18:1-25.

4) Hashimoto $H$, Nomoto $A$, Watanabe $K$, Mori T, Takezawa T, Arizawa C, Takegami T, Hiramatsu K. Molecular cloning and complete nucleotide sequence of the genome of Japanese encephalitis virus Beijing-1 strain. Virus Genes 1988;1:305-17.

5) World Health Organization Japanese encephalitis vaccines. Wkly Epidemiol Rec 1998;73:334-44.

6) Hanna JN, Ritchie SA, Phillips DA, Lee JM, Hills SL, van den Hurk AF, Pyke AT, Johansen CA, Mackenzie JS. Japanese encephalitis in north Queensland, Australia. 1998. Med J Aust 1999;170:533-6.

7) Mackenzie JS, Poidinger M, Phillips DA, Johansen CA, Hall RA, Hanna JN, Ritchie SA, Shield J, Graham R. 1997. Emergence of Japanese encephalitis virus in the Australian region, In Saluzzo J, Dodet B (eds.), Factors in the Emergence 
of Arboviruses Diseases, pp.191-201, Elsevier, Paris.

8) Shield J, Hanna JN, Phillips DA. Reappearance of the Japanese encephalitis virus in the Torres Strait. Comm Dis Intel 1996; 20:191.

9) Spicer PE, Phillips D, Pike A, Johansen C, Melrose W, Hall RA. Antibodies to Japanese encephalitis virus in human sera collected from Irian Jaya: Follow-up of a previously reported case of Japanese encephalitis in that region. Trans R Soc Trop Med Hyg 1999;93:511-4.

10) Rice CM. 1996. Flaviviridae: The viruses and their replication, In Fields BN, Knipe DM, Howley PM (eds.), Fields Virology, $3^{\text {rd }}$ ed, pp.931-960, Lippincott-Raven Publishers, Philadelphia.

11) Thiel HJ, Plagemann PGW, Moennig V. 1996. Pestiviruses, In Fields BN, Knipe DM, Howley PM (eds.), Fields Virology, $3^{\text {rd }}$ ed, pp.1059-1073, Lippincott-Raven Publishers, Philadelphia.

12) Burke DS, Monath TP. 2001. Flaviviruses, In Knipe DM, Howley PM, Griffin DE, Lamb RA, Martin MA, Roizman B, Straus SE (eds.), Fields Virology, $4^{\text {th }}$ ed, pp.1043-1125, Lippincortt Williams \& Wilkins, Philadelphia.

13) Lindenbach BD, Rice CM. 2001. Flaviviridae: The viruses and their replication, In Knipe DM, Howley PM, Griffin DE, Lamb RA, Martin MA, Roizman B, Straus SE (eds.), Fields Virology, $4^{\text {th }}$ ed, pp.991-1041, Lippincortt Williams \& Wilkins, Philadelphia.

14) Chambers TJ, Hahn CS, Galler R, Rice CM. Flavivirus genome organization, expression, and replication. Annu Rev Microbiol 1990;44:649-88.

15) Egloff MP, Benarroch D, Selisko B, Romette JL, Canard B. An RNA cap (nucleoside-2'-O-)-methyltransferase in the flavivirus RNA polymerase NS5: crystal structure and functional characterization. EMBO J 2002;21:2757-68.

16) Koonin EV. Computer-assisted identification of a putative methyltransferase domain in NS5 protein of flaviviruses and lambda 2 protein of reovirus. J Gen Virol 1993;74:733-40.

17) Ackermann M, Padmanabhan R. De novo synthesis of RNA by the dengue virus RNA-dependent RNA polymerase exhibits temperature dependence at the initiation but not elongation phase. J Biol Chem 2001;276:39926-37.

18) Guyatt KJ, Westaway EG, Khromykh AA. Expression and purification of enzymatically active recombinant RNAdependent RNA polymerase (NS5) of the flavivirus Kunjin. J Virol Methods 2001;92:37-44.
19) Tan BH, Fu J, Sugrue RJ, Yap EH, Chan YC, Tan YH. Recombinant dengue type 1 virus NS5 protein expressed in Escherichia coli exhibits RNA-dependent RNA polymerase activity. Virology 1996;216:317-25.

20) Medin CL, Fitzgerald KA, Rothman AL. Dengue virus nonstructural protein NS5 induces interleukin-8 transcription and secretion. J Virol 2005;79:11053-61.

21) Best SM, Morris KL, Shannon JG, Robertson SJ, Mitzel DN, Park GS, Boer E, Wolfinbarger JB, Bloom ME. Inhibition of interferon-stimulated JAK-STAT signaling by a tick-borne flavivirus and identification of NS5 as an interferon antagonist. J Virol 2005;79:12828-39.

22) Yun SI, Kim SY, Choi WY, Nam JH, Ju YR, Park KY, Cho HW, Lee YM. Molecular characterization of the full-length genome of the Japanese encephalitis viral strain K87P39. Virus Res 2003;96:129-40.

23) Sambrook J, Fritsch EF, Maniatis T. 1989. Molecular cloning: a laboratory manual, second ed., Cold Spring Harbor Laboratory, New York.

24) Ray D, Shah A, Tilgner M, Guo Y, Zhao Y, Dong H, Deas TS, Zhou Y, Li H, Shi PY. West Nile virus 5'-cap structure is formed by sequential guanine $\mathrm{N}-7$ and ribose 2'-O methylations by nonstructural protein 5. J Virol 2006;80:8362-70.

25) Zhou Y, Ray D, Zhao Y, Dong H, Ren S, Li Z, Guo Y, Bernard KA, Shi PY, Li H. Structure and function of flavivirus NS5 methyltransferase. J Virol 2007;81:3891-903.

26) Dong H, Ray D, Ren S, Zhang B, Puig-Basagoiti F, Takagi Y, Ho CK, Li H, Shi PY. Distinct RNA elements confer specificity to flavivirus RNA cap methylation events. J Virol 2007;81: 4412-21.

27) Alvarez DE, De Lella Ezcurra AL, Fucito S, Gamarnik AV. Role of RNA structures present at the 3'UTR of dengue virus on translation, RNA synthesis, and viral replication. Virology 2005;339:200-12.

28) Filomatori CV, Lodeiro MF, Alvarez DE, Samsa MM, Pietrasanta L, Gamarnik AV. A 5' RNA element promotes dengue virus RNA synthesis on a circular genome. Genes Dev 2006;20:2238-49

29) Lodeiro MF, Filomatori CV, Gamarnik AV. Structural and functional studies of the promoter element for dengue virus RNA replication. J Virol 2009;83:993-1008. 